\title{
Assessment of soil quality parameters and yield of rice cultivars in Melaleuca cajuputi agroforestry system
}

\author{
PRIYONO SURYANTO ${ }^{1, \bullet}$, TARYONO ${ }^{2,4}$, SUPRIYANTA $^{2}$, DODY KASTONO ${ }^{2}$, EKA TARWACA SUSILA PUTRA ${ }^{2}$, \\ SUCI HANDAYANI ${ }^{3}$, MUHAMMAD HABIB WIDYAWAN ${ }^{2}$, TAUFAN ALAM ${ }^{2, \vee v}$ \\ ${ }^{1}$ Department of Silviculture, Faculty of Forestry, Universitas Gadjah Mada. Jl. Agro No. 1, Bulaksumur, Sleman 55281, Yogyakarta, Indonesia. \\ Tel.: +62-274-512102; Fax.: +62-274-550541, `email: psuryanto@ugm.ac.id \\ ${ }^{2}$ Department of Agronomy, Faculty of Agriculture, Universitas Gadjah Mada. Jl. Flora No. 1, Bulaksumur, Sleman 55281, Yogyakarta, Indonesia. \\ Tel.: +62-274-563062, 901290, Fax.: +62-274-563062, 519717, ^vemail: taufan.alam@ugm.ac.id \\ ${ }^{3}$ Department of Soil, Faculty of Agriculture, Universitas Gadjah Mada. Jl. Flora No. 1, Bulaksumur, Sleman 55281, Yogyakarta, Indonesia \\ ${ }^{4}$ Agrotechnology Innovation Center, Universitas Gadjah Mada, Indonesia. Kalitirto, Berbah, Sleman 55573, Yogyakarta, Indonesia
}

Manuscript received: 29 June 2020. Revision accepted: 6 July 2020.

\begin{abstract}
Suryanto P, Taryono, Supriyanta, Kastono D, Putra ETS, Widyawan MH, Alam T. 2020. Assessment of soil quality parameters and yield of rice cultivars in Melaleuca cajuputi agroforestry system. Biodiversitas 21: 3463-3470. Interactions between rice cultivars and soil quality parameters rises problems in the attempt of increasing rice yield. The objective of this study was to assess soil quality parameters that affect the yield of 15 rice cultivars in an agroforestry system of 'kayu putih' (Melaleuca cajuputi) situated in Menggoran forest, Yogyakarta, Indonesia which have three soil types namely Lithic Haplusterts, Ustic Epiaquerts, and Vertic Haplustalfs. The observation was conducted on 21 soil quality parameters and yield of rice cultivars. The data were analyzed by using ANOVA, factor analysis, and stepwise regression. The highest yield of rice per hectare was attained by GM 28 in Ustic Epiaquerts with 6.493 tons ha ${ }^{-1}$, while Situ Patenggang and GM 28 in Vertic Haplustalfs as high as5.549 and 5.401 tons ha $^{-1}$, respectively, and Situ Patenggang in Lithic Haplusterts as high as 4.893 tons ha-1. Soil quality parameters that had significant effect on the yield of rice cultivars were Clay, SMC, pH, SOC, N, Mg, Fe, Fg, and Bae. We suggested that rice cultivars recommendations for Lithic Haplusterts, Ustic Epiaquerts, and Vertic Haplustalfs are Situ Patenggang, Situ Patenggang or GM 28, and GM 28, respectively, in addition to fertilization based on limiting factors of each rice cultivars..
\end{abstract}

Keywords: Agroforestry, Melaleuca cajuputi, rice cultivars, soil quality assessment, soil types

Abbreviations: Al: aluminum exchange, Bae: amounts of bacterium, BD: bulk density, Ca: available of calcium, CEC: cation exchange capacity, Clay: \% clay, EC: electrical conductivity, Fe: available of iron, Fg: amounts of fungi, K: available of potassium, k: permeability, Mg: available of magnesium, Mn: available of manganese, $\mathrm{N}$ : total nitrogen, Na: available of sodium, P: available of phosphorus, pH: $\mathrm{pH} \mathrm{H}_{2} \mathrm{O}$, Sand: \% sand, Silt: \% silt, SMC: soil moisture content, SOC: soil organic carbon

\section{INTRODUCTION}

Rice (Oryza sativa L.) is the main crop for half of the world's population (Fan et al. 2016). In 2050, an additional 100 million tons of rice is needed to feed 9.1 billion people (Jaggard et al. 2010). Yet, the land available for rice farming continues to decrease. For example, Indonesia loses 96,512 hectares of rice field per year, and if this trend continues the existing rice field area of 8.1 million hectares will be reduced to only around 5.1 million hectares in 2045 (Mulyani et al. 2017). In just one year alone from 2018 to 2019 , the harvested area of rice agriculture in Indonesia shrunk by 700,000 hectares $(6.15 \%)$ with rice production reduced by 4.60 million tons $(7.76 \%)$ (Statistics Indonesia 2020).

One strategy to expand the area of rice farming is by planting rice on tree-based land-use system, or so-called agroforestry. There are various species composition of trees, perennial crops, and annual crops in agroforestry, one of which is the use of 'kayu putih' (Melaleuca cajuputi Powell) as tree layer. Agroforestry system with the base of
M. cajuputi stands is presumably suitable to be combined with rice since the leaves and branches of $M$. cajuputi are pruned routinely so that there is no shade effect for rice (Alam et al. 2019; Suryanto et al. 2017a; Suryanto et al. 2017c; Suryanto et al. 2020a; Suryanto et al. 2020c).

While combining rice and trees, such as 'kayu putih', in an agroforestry system is a promising strategy, there is a problem related to how to increase rice yield by selecting superior rice cultivars that givehigh yield potential. The problem arises since there isinteractions between genetic factors and environmental factors, resulting inspecific cultivars only grow best on specific environment (Piepho et al. 2016). It means that cultivars that high yielding are not necessarily suitable and stable for all environments. Therefore, selecting best rice cultivars that suit environmental conditions is one of the key factors to maximize the yield potential and very important to do before giving a recommendation of these cultivars to farmers (Alam et al. 2019; Piepho et al. 2016). Beside they suit the environment conditions, the selected rice cultivars 
should be accessibleand highly applicable to ease adoption by the farmers (Zaini et al. 2016).

One of environment factors to consider when selecting rice cultivars is soil types (Alam et al. 2019). The selection of rice cultivars can be made by assessing the limiting factors in the form of soil quality parameters in each rice cultivar. The right selection of rice cultivars that suit with soil type can maximize the yield potential of these cultivars and reduce the input of inorganic fertilizers (European Union 2012). Soil type determines soil quality in terms of the physical, chemical, and biological characteristics of the soil, as well as the most suitable land management practices, carried out by farmers (Bilgili et al. 2017).

Assessment on soil quality is highly dependent on the diversity of locations, scale, land management, and research objectives (Rousseau et al. 2012). Several studies related to soil quality assessment showed that each commodity has specific requirements and limiting factors related to soil properties (Suryanto et al. 2017a; Suryanto et al. 2020b). For example, there soil quality parameters affect the growth and yield production of clove, cocoa, and cardamom even when they were grown on the same location in Menoreh Mountain, Indonesia (Suryanto et al. 2017b). The dry weight of clove flower was affected by $\%$ silt, while the dry weight of cocoa beans was affected by $\mathrm{CEC}, \mathrm{Ca}$, and $\mathrm{Na}$, and the dry weight of cardamom bulbs by $\mathrm{Ca}$ (Suryanto et al. 2017b). Other research conducted on the mountain ecosystem showed that increased signal grass production was very significantly influenced by the increase in CEC, SOC, air temperature, and wind speed (Suryanto et al. 2020b).

Similar studies to assess the effect of soil quality on the growth and yield of rice had been carried, but these were without considering the factor of rice cultivars. The study results showed that soil quality parameters or soil properties that influenced rice yield were the amounts of soil microorganisms, availability of phosphorus, and potassium (Suryanto et al. 2017a). The objective of this study was to investigate soil quality parameters in terms of physical, chemical, and biological properties that affect the yield of 15 rice cultivars in an agroforestry system of $M$. cajuputi in Menggoran forest, Yogyakarta, Indonesia. The results of this study will provide information to farmers, researchers, and policymakers on how to increase the productivity of rice cultivars in $M$. cajuputi agroforestry system based on soil quality limiting factors.

\section{MATERIALS AND METHODS}

\section{Study period and area}

The study was conducted during November-February, 2020 in Menggoran Forest Resort, Playen Forest Section, Yogyakarta Forest Management District, Indonesia. This area is located $\pm 43 \mathrm{~km}$ to the southeast of Yogyakarta City (Figure 1.A) (Alam et al. 2019; Suryanto et al. 2020a; Suryanto et al. 2020c). The altitude of the study site is \pm 100 meters above sea level. The total rainfall observed during the experiment was $\pm 1,182 \mathrm{~mm}$. The average air temperature and the relative humidities were $29.38^{\circ} \mathrm{C}$ and
$81.90 \%$, respectively. The area in the $M$. cajuputi forest belongs to the Department of Forestry and Plantation, Yogyakarta, Indonesia. The age of $M$. cajuputi trees in the study area was \pm 15 year and harvested/pruned every six months (Haryanto 2015). Farmers are free to use land between $M$. cajuputi stands for annual crop cultivation and not taxed and rent land. Nevertheless, farmers are required to tend for $M$. cajuputi trees and pruned routinely every six months. Common cropping patterns in a year for farmers in $M$. cajuputi forest are rice-maize/soybean/peanut-fallow (Figures 1.B and 1.C). Fallow is the stage of crop rotation in which the land is deliberately not used to raise a crop (Feng and Balkcom 2017).

\section{Experimental design}

All the trials were laid out in a Randomized Complete Block Design (RCBD) with two factors/treatments with five blocks as replications. The first factor was rice cultivars, consisted of eleven major rice cultivars that mostly used by farmers in Indonesia and four promising lines sourced from Faculty of Agriculture, Universitas Gadjah Mada, Indonesia. The eleven rice cultivars consisted of Ciherang, Inpago 4, Inpago 5, Inpago 6, Inpari 6 Jete, Inpari 33, IR-64, Puthu Gunungkidul, Situ Bagendit, Situ Patenggang, and Way Apo Buru, while the four promising lines consisted of GM 2, GM 8, GM 11, and GM 28.

The second factor was soil type, consisted of three soil types namely Lithic Haplusterts, Ustic Epiaquerts, and Vertic Haplustalfs. The experimental plot covered an area of $24 \mathrm{~m}^{2}(6 \times 4 \mathrm{~m})$ within the space of $M$. cajuputi stands with the harvest area of $20 \mathrm{~m}^{2}$ as the border rows were excluded. Soil tillage was carried out before planting rice with a hand tractor. Rice planting was carried out by direct seeded planting method. The number of seeds per planting hole was two seeds with a spacing of $20 \times 20 \mathrm{~cm}$. No fertilizer and pesticides were applied in this study, neither did the irrigation because the field was in the rainfed areas.

\section{Soil quality parameters}

The observed parameters were \% soil texture (Clay, Sand, Silt) (Aubert et al. 1954), bulk density (BD) (Blake and Hartge 1986), soil moisture content (SMC) (Alam 2014), permeability (k) (Blake and Hartge 1986), $\mathrm{pH} \mathrm{H}_{2} \mathrm{O}$ (pH) (Van Reeuwijk 1993), soil organic carbon (SOC) (Black 1965), cation exchange capacity (CEC) (Hajek et al. 1972; Van Reeuwijk 1993), electrical conductivity (EC) (Richards 1954), total nitrogen (N) (Stenholm et al. 2009), available of phosphorus (P) (Olsen et al. 1954), available of potassium $(\mathrm{K})$, sodium $(\mathrm{Na})$, calcium $(\mathrm{Ca})$, iron $(\mathrm{Fe})$, and manganese (Mn) (Jones Jr 2001; Van Reeuwijk 1993), aluminum exchange (Al) (Jones Jr 2001; Van Reeuwijk 1993), and amounts of bacterium (Bae) and fungi (Fg) (David and Davidson 2014). The observed parameters were analyzed at the initial of the study, while the SMC observed in once a week. The observations were carried out at the study site and in General Soil and Microbiology Laboratory, Faculty of Agriculture, Universitas Gadjah Mada, Yogyakarta, Indonesia. 

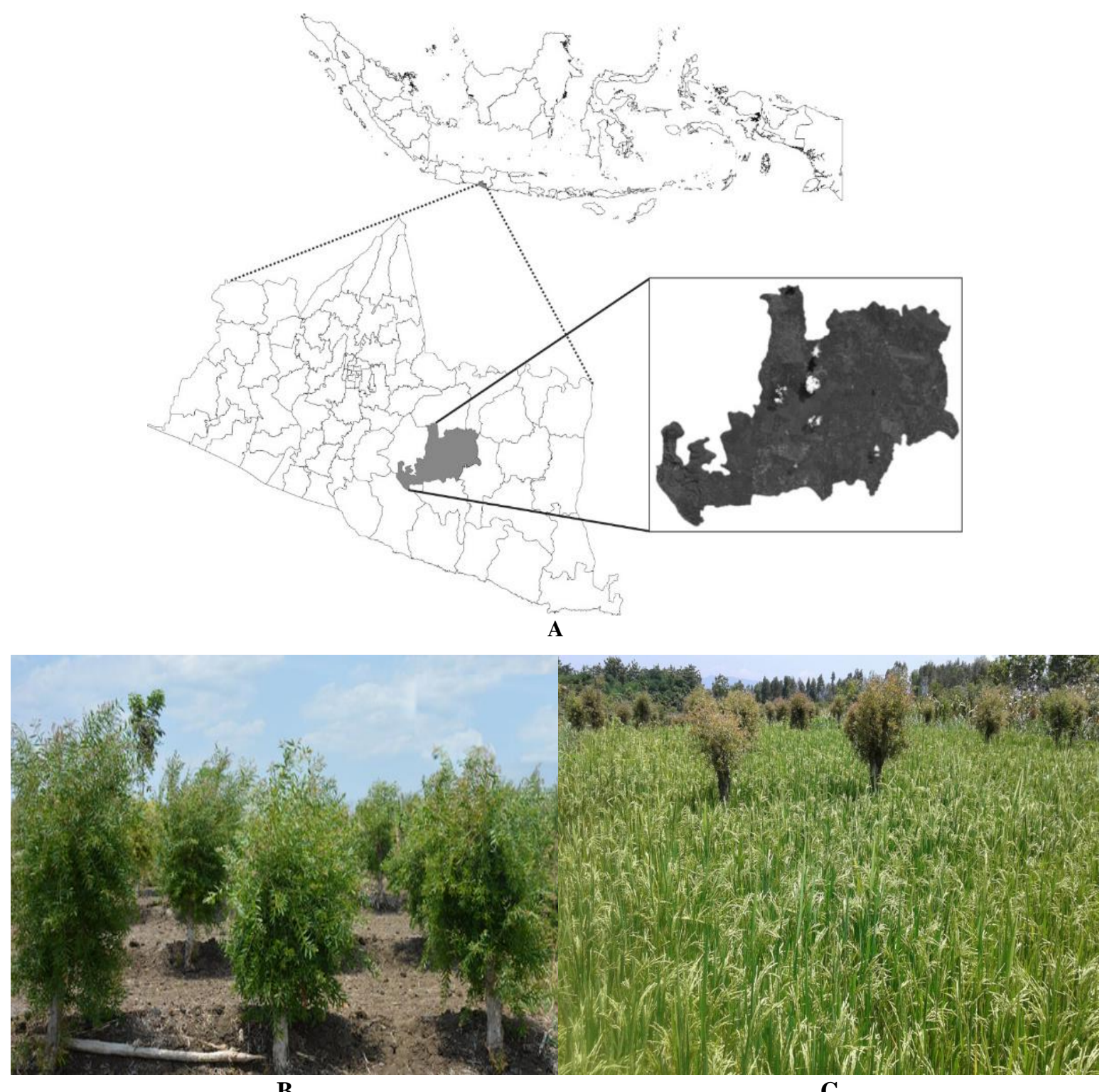

B

C

Figure 1. A. Geographical location of the study area ( $7^{\circ} 52^{`} 59.5992^{\prime \prime} \mathrm{S}$ to $7^{\circ} 59^{`} 41.1288^{\prime \prime} \mathrm{S}$ and $110^{\circ} 26^{\prime} 21.462^{\prime \prime} \mathrm{E}$ to $110^{\circ} 35^{\prime} 7.4868^{\prime \prime}$ E). B. Melaleuca cajuputi forest without annual crops in fallow periods. C. Rice cultivation between M. cajuputi stands

\section{Rice yield variable}

The observed of rice parameters was rice yield per hectare. Rice grains were dried under the sunlight to reach $11 \%$ of moisture level (Suryanto et al. 2020a; Suryanto et al. 2020c).

\section{Statistical analysis}

The models must be evaluated so that assumptions can be fulfilled. The normality test was carried out using the Kolmogorov test and Q-Q plot (Moncada et al. 2014). Two-way ANOVA was used to test the yield of rice cultivars in different soil types and the separation of means was subject to the Scott-Knott test $(\mathrm{p}<0.05)$ (Hinkelman and Kempthorne 2008).

One-way ANOVA, factor analysis, and stepwise regression were used to investigate the relationship between soil quality parameters with the yield of rice cultivars (Andrews et al. 2002; Govaerts et al. 2006; Suryanto et al. 2017a; Suryanto et al. 2020b). Factor analysis is commonly used because of it's ability to group related soil properties into a small set of independent factors and to reduce the original data set (Andrews et al. 2002). Factor analysis is widely considered as a suitable method for highly correlated environmental data (Govaerts et al. 2006; Yao et al. 2013). Varimax rotation enhances the interpretability of the uncorrelated components. The derived factors are designated as soil quality indices or complex indicators.

ANOVA, factor analysis, and stepwise regression were carried out using SAS software version 9.4 for Windows. Statistical analysis was carried out by PROC GLM, MIXED, PRINCOMP, FACTOR, and REG (SAS Institute Inc 2013). 


\section{RESULTS AND DISCUSSION}

\section{Characteristic of study sites}

The study site had ustic soil moisture regime (Alam et al. 2019; Suryanto et al. 2017a; Suryanto et al. 2020a; Suryanto et al. 2020c). Ustic is a soil regime containing limited moisture but is suitable for plant growth when the environmental conditions favorable. The soil is intermittently moist and dry. Moisture is limited but usually available during portions of the growing season. In most years, the soil is moist $>180$ cumulative days or $>90$ consecutive days (Boettinger et al. 2015).

The first soil type was classified as Lithic Haplusterts (Alam et al. 2019; Suryanto et al. 2017a; Suryanto et al. 2020a; Suryanto et al. 2020c). Lithic Haplusterts is a Vertisol soil type that has shallow solum and a lithic contact within $50 \mathrm{~cm}$ of the soil surface (Boettinger et al. 2015). The seasonal cracking pattern pertains to nonirrigated soils. Cracks are $>5 \mathrm{~mm}$ wide and extend through $>25 \mathrm{~cm}$ within $50 \mathrm{~cm}$ of the soil surface. They have little or no accumulation of salts with a $\mathrm{pH}$ value of $>5.0$ (in $1: 1$ water). These soils are derived from a variety of parent materials, including sedimentary rocks, alluvium, marl, and basic igneous rocks. Slopes range from nearly level to strongly sloping (Boettinger et al. 2015).

The second soil type was Vertic Haplustalfs as Alfisols soil type with vertic characteristic and have an argillic (clay accumulation) subsoil horizon with a significant decrease in clay content within a depth of $150 \mathrm{~cm}$. These soils have a lithic contact within $50 \mathrm{~cm}$ of the mineral soil surface (Alam et al. 2020; Suryanto et al. 2017a; Suryanto et al. 2020a; Suryanto et al. 2020c). The third soil type was Ustic Epiaquerts as Vertisols soil type that has a fracture of $>5$ $\mathrm{mm}$ and thickness of $>25 \mathrm{~cm}$ for 90 days each year in a reasonable condition when it is not irrigated (Alam et al. 2019). These soils have one or more soil layers that perch water. These layers are commonly close to the surface. Epiaquerts occur on a variety of landforms, including flood plains, glacial lake plains, and depressions (Boettinger et al. 2015). In general, rice is marginally suitable to be planted in Lithic Haplusterts and Vertic Haplustalfs, while it is suitable to be planted in Ustic Epiaquerts because of the land is flooded during the wet season (Wahyunto et al. 2016; Wahab et al. 2017).

\section{Influence of soil types on rice cultivars yield in Melaleuca cajuputi agroforestry system}

The result of two-way ANOVA $(\mathrm{p}<0.05)$ revealed that there was an interaction between soil types and rice cultivars concerning the yield of rice per hectare (Table 1). The highest yield per hectare was found in GM 28 when planted in Ustic Epiaquerts with 6.493 tons ha ${ }^{-1}$, while Situ Patenggang and GM 28 in Vertic Haplustalfs yielded 5.549 and 5.401 tons ha ${ }^{-1}$, respectively, and Situ Patenggang in Lithic Haplusterts yielded 4.893 tons ha $^{-1}$. The lowest yield per hectare was found in local cultivar of Puthu Gunungkidul when planted in Lithic Haplusterts and Vertic Haplustalfs with 2.078 and 2.485 tons ha $^{-1}$, respectively, while Inpago 6 in Ustic Epiaquerts resulted in 2.078 tons ha $^{-1}$.

In general, GM 28 cultivar gave the highest yield of 5.554 tons $\mathrm{ha}^{-1}$, while the Inpago 6 cultivar gavethe lowest yield of 2.239 tons $\mathrm{ha}^{-1}$ in all soil types. The mean yield of rice cultivars for the three types of soil from highest to lowest was Ustic Epiaquerts, Vertic Haplustalfs, and Lithic Haplusterts with values of 4.349, 3.573, and 2.906 tons ha1 , respectively. Study results indicate that the yield per hectare at the study site was below the yield potential, thereby requiring an assessment to improve the yield of rice cultivars seen from soil quality parameters (Jamil et al. 2016).

\section{Selection of key soil quality parameters for yield improvement of rice cultivars}

The selection of soil quality parameters used as sustainability indicators for the yield of rice cultivar was carried out by ANOVA, factor analysis, and stepwise regression. The first step was selection of key parameters using ANOVA. The parameters that showed a significant difference ( $\mathrm{p}<0.05$ ) and had a coefficient of variance $<40 \%$ would be followed by factor analysis. Table 2 reveals that soil parameters that had significant effect on the yield of rice cultivar are clay, silt, SMC, $\mathrm{pH}$, SOC, CEC, EC, N, P, K, Na, Ca, Mg, Fe, Bae, and Fg. These parameters were then subjected for factor analysis.

The result of the factor analysis shows two groups of soil quality factors (Table 3). Factor 1 consists of clay, silt, $\mathrm{pH}, \mathrm{CEC}, \mathrm{EC}, \mathrm{N}, \mathrm{P}, \mathrm{K}, \mathrm{Ca}, \mathrm{Mg}$, and $\mathrm{Na}$, while factor 2 consists of clay, silt, SMC, SOC, N, P, Mg, Bae, and Fg. The final result of the factor analysis shows that clay, silt, SMC, pH, CEC, EC, N, P, K, Ca, Mg, Na, Bae, and Fg were suitable to proceed to the stepwise regression analysis since it has communality values of higher than 0.5 .

The result of stepwise regression shows that each rice cultivar has different limiting factors in soil quality parameters (Table 4). This means that each rice cultivar requires different set of soil quality parameters. The soil quality parameters affecting the yield of Ciherang were SMC $(0.001 * *)$ and $\mathrm{N}(12.122 * *)$, GM 2 were SMC $(0.001 * *)$ and $\mathrm{Mg}(0.792 * *), \mathrm{GM} 8$ was $\mathrm{N}(33.352 * *), \mathrm{GM}$ 11 were SMC $(0.002 * *)$ and SOC $(1.257 * *)$, GM 28 were SOC $\left(2.639^{* *}\right)$ and SMC $(0.001 * *)$, Inpago 4 was Bae $\left(0.833^{* *}\right)$, Inpago 5 was Bae $\left(0.775^{* *}\right)$, Inpago were Clay $\left(0.020^{* *}\right)$ and SOC $(0.597 * *)$, Inpari 6 Jete were SMC $(0.003 * *)$ and $\mathrm{Fe}(0.164 *)$, Inpari 33 were SMC $(0.002 * *)$ and $\operatorname{SOC}(0.593 *)$, IR-64 were $\operatorname{SMC}(0.002 * *)$ and $\mathrm{Mg}$ $\left(0.478^{* *}\right)$, Puthu Gunungkidul were $\mathrm{Fg}(2.334 * *)$ and $\mathrm{pH}$ $\left(-0.456^{* *}\right)$, Situ Bagendit were Clay $\left(0.023^{*}\right)$ and $\mathrm{pH}$ $\left(0.141^{*}\right)$, Situ Patenggang was Clay $\left(0.074^{* *}\right)$, while Way Apo Buru were Fg $(2.614 * *)$ and $\mathrm{pH}(-0.491 * *)$.

\section{Discussion}

Rice cultivars showed differences in yield per hectare when planted in Lithic Haplusterts, Ustic Epiaquerts, and Vertic Haplustalfs. It depends on the genetics of each plant so that it affects the adaptability of plants to environmental factors (Klee and Tieman 2013). The difference in the yield of rice cultivars was caused by differences in soil quality in each soil type. Soil quality was an important element for plant growth. Rice cultivars showed different biochemical, physiological, and yield responses under different environmental conditions (Boy et al. 2020). 
Table 1. Yield per hectare (tons ha ${ }^{-1}$ ) of rice cultivars planted on three soil types in Melaleuca cajuputi agroforestry system

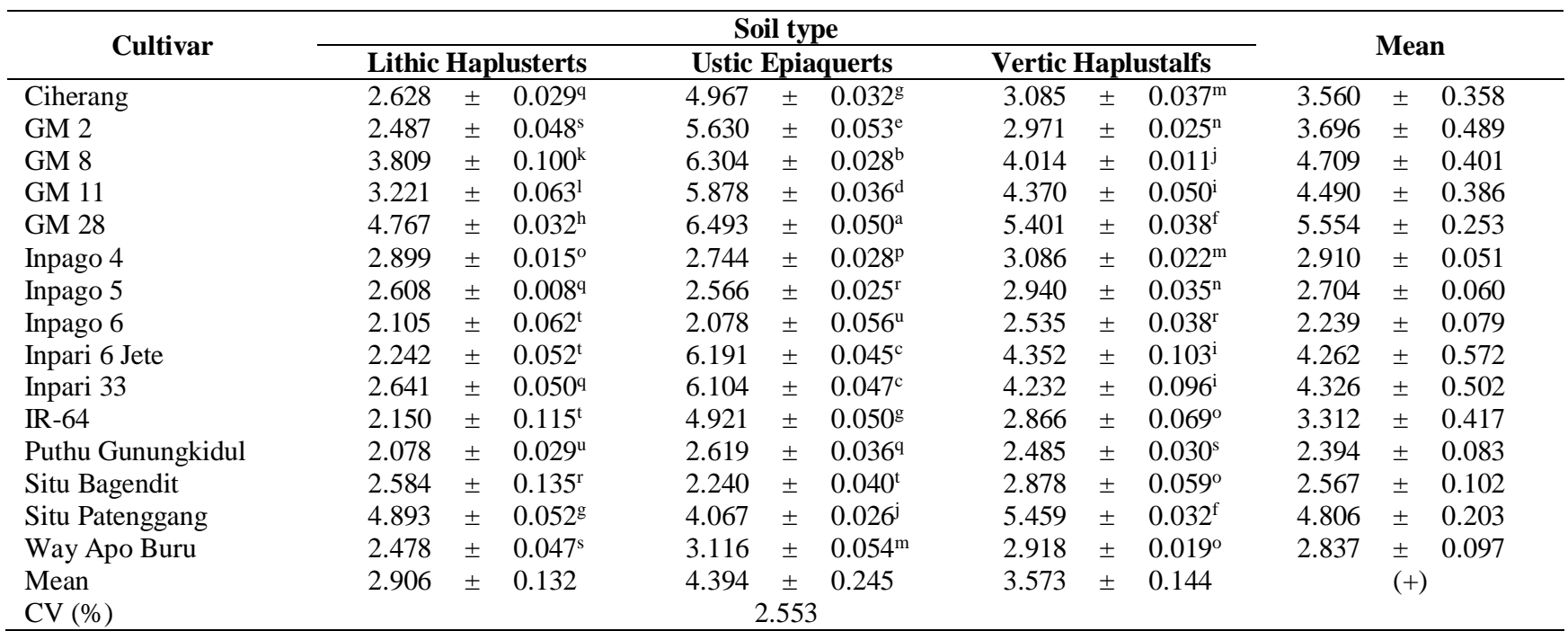

Notes: Numbers within a column show the mean and standard error of the mean (SEM). Numbers followed by the same letters in the same row and column were not significantly different by Scott-Knott test $(\mathrm{p}<0.05)$

Table 2. The soil quality factors affecting the yield of rice cultivars

\begin{tabular}{|c|c|c|c|c|}
\hline \multirow{2}{*}{$\begin{array}{c}\text { Soil } \\
\text { properties }\end{array}$} & \multirow{2}{*}{$\begin{array}{l}\text { Soil quality } \\
\text { parameters }\end{array}$} & \multicolumn{2}{|c|}{$\begin{array}{c}\text { Mean squares treatment } \\
\text { ANOVA }\end{array}$} & \multirow{2}{*}{$\begin{array}{l}\text { CV } \\
(\%)\end{array}$} \\
\hline & & Error & Treatment & \\
\hline \multirow{6}{*}{$\begin{array}{l}\text { Physical } \\
\text { properties }\end{array}$} & Clay & 21.803 & $197.319 *$ & 7.229 \\
\hline & Sand & 2.172 & $3.870^{\mathrm{ns}}$ & 21.562 \\
\hline & Silt & 13.489 & $148.571 *$ & 12.855 \\
\hline & $\mathrm{BD}$ & 0.004 & $0.005^{\mathrm{ns}}$ & 5.707 \\
\hline & SMC & 0.003 & $0.549 * *$ & 1.2061 \\
\hline & $\mathrm{k}$ & 0.000 & $0.000-$ & - \\
\hline \multirow{13}{*}{$\begin{array}{l}\text { Chemical } \\
\text { properties }\end{array}$} & $\mathrm{pH}$ & 0.003 & $0.112 * *$ & 0.646 \\
\hline & $\mathrm{SOC}$ & 0.001 & $0.015 * *$ & 1.659 \\
\hline & CEC & 0.058 & $480.296 * *$ & 0.458 \\
\hline & $\mathrm{EC}$ & 0.007 & $0.305 * *$ & 5.588 \\
\hline & $\mathrm{N}$ & 0.00001 & $0.001 * *$ & 3.706 \\
\hline & $\mathrm{P}$ & 0.463 & $26.519 * *$ & 9.463 \\
\hline & $\mathrm{K}$ & 0.002 & $0.016 *$ & 11.626 \\
\hline & $\mathrm{Na}$ & 0.009 & $0.137 *$ & 20.818 \\
\hline & $\mathrm{Ca}$ & 1.785 & $14.540 *$ & 5.512 \\
\hline & $\mathrm{Mg}$ & 0.005 & $0.915 * *$ & 3.579 \\
\hline & $\mathrm{Fe}$ & 0.044 & $4.970 * *$ & 9.150 \\
\hline & $\mathrm{Mn}$ & 0.022 & $0.054^{\mathrm{ns}}$ & 4.387 \\
\hline & $\mathrm{Al}$ & 0.063 & $0.066^{\mathrm{ns}}$ & 15.782 \\
\hline Biological & $\mathrm{Bae}$ & $1.11 \times 10^{9}$ & $1.11 \times 10^{10 *}$ & 0.955 \\
\hline properties & $\mathrm{Fg}$ & $1.66 \times 10^{7}$ & $1.33 \times 10^{8} *$ & 1.590 \\
\hline
\end{tabular}

Giller et al. (2011) informed that each plant has a different response in absorbing nutrients and fertilizers in a location. This showed that the soil had a high heterogeneity that affects plant growth. The results of this study showed that soil quality parameters that had significant effect on the yield of rice cultivars in $M$. cajuputi agroforestry systems were Clay, SMC, pH, SOC, N, Mg, Fe, Fg, and Bae.
Table 3. Factor analysis with varimax rotation of physical, chemical, and biological properties of the soils

\begin{tabular}{lrrrrc}
\hline \multicolumn{1}{r}{ Parameter } & \multicolumn{1}{c}{ Factor 1 } & \multicolumn{1}{c}{ Factor 2 } & Communality \\
\hline Clay & -0.774 & $*$ & -0.539 & $*$ & 0.889 \\
Silt & 0.793 & $*$ & 0.528 & $*$ & 0.907 \\
SMC & -0.066 & & 0.935 & $*$ & 0.878 \\
pH & 0.903 & $*$ & -0.210 & & 0.860 \\
SOC & 0.205 & & 0.881 & $*$ & 0.818 \\
CEC & 0.903 & $*$ & 0.412 & & 0.985 \\
EC & 0.859 & $*$ & 0.470 & & 0.958 \\
N & 0.532 & $*$ & 0.796 & $*$ & 0.917 \\
P & 0.661 & $*$ & 0.718 & $*$ & 0.952 \\
K & 0.654 & $*$ & 0.455 & & 0.635 \\
Ca & 0.926 & $*$ & -0.224 & & 0.908 \\
Mg & 0.565 & $*$ & 0.798 & $*$ & 0.957 \\
Na & 0.944 & $*$ & 0.215 & & 0.938 \\
Fe & -0.981 & $*$ & -0.174 & & 0.993 \\
Bae & 0.048 & \multicolumn{5}{c}{0.912} & $*$ & 0.834 \\
Fg & 0.076 & 0.935 & $*$ & 0.880 \\
Eigenvalues & 10.689 & 3.621 & \\
\hline Notes: * Parameter had significant value in each group of soil factor
\end{tabular}

Table 4. Stepwise regression analysis of relationship between soil quality parameters with yield of rice cultivars

\begin{tabular}{|c|c|c|}
\hline Cultivars & Regression Equations & $\mathbf{R}^{2}$ \\
\hline Ciherang & $\mathrm{y}=0.001 \mathrm{SMC}^{* *}+12.122 \mathrm{~N} * *$ & $0.999 * *$ \\
\hline GM 2 & $\mathrm{y}=0.001 \mathrm{SMC}^{* *}+0.792 \mathrm{Mg}^{* *}$ & $0.997 * *$ \\
\hline GM 8 & $\mathrm{y}=33.352 \mathrm{~N}^{* *}$ & $0.991 * *$ \\
\hline GM 11 & $\mathrm{y}=0.002 \mathrm{SMC}^{* *}+1.257 \mathrm{SOC}^{* *}$ & $0.998 * *$ \\
\hline GM 28 & $\mathrm{y}=2.639 \mathrm{SOC}^{* *}+0.001 \mathrm{SMC}^{* *}$ & $0.999 * *$ \\
\hline Inpago 4 & $\mathrm{y}=0.833 \mathrm{Bae}^{* *}$ & $0.996 * *$ \\
\hline Inpago 5 & $\mathrm{y}=0.775 \mathrm{Bae}^{* *}$ & $0.995 * *$ \\
\hline Inpago 6 & $\mathrm{y}=0.020$ Clay $^{* *}+0.597 \mathrm{SOC}^{* *}$ & $0.997 * *$ \\
\hline Inpari 6 Jete & $\mathrm{y}=0.003 \mathrm{SMC}^{* *}+0.164 \mathrm{Fe}^{*}$ & $0.996^{* *}$ \\
\hline Inpari 33 & $\mathrm{y}=0.002 \mathrm{SMC}^{* *}+0.593 \mathrm{SOC}^{*}$ & $0.996^{* *}$ \\
\hline IR-64 & $\mathrm{y}=0.002 \mathrm{SMC}^{* *}+0.478 \mathrm{Mg}^{* *}$ & $0.998 * *$ \\
\hline Puthu & $\mathrm{y}=2.334 \mathrm{Fg}^{* *}-0.456 \mathrm{pH}^{* *}$ & $0.999 * *$ \\
\hline Gunungkidul & & \\
\hline Situ Bagendit & $\mathrm{y}=0.023$ Clay $*+0.141 \mathrm{pH}^{*}$ & $0.994 * *$ \\
\hline Situ Patenggang & $\mathrm{y}=0.074$ Clay $* *$ & $0.993 * *$ \\
\hline Way Apo Buru & $\mathrm{y}=2.614 \mathrm{Fg}^{* *}-0.491 \mathrm{pH}^{* *}$ & $0.998 * *$ \\
\hline
\end{tabular}


The high portion of clay in the soil had very significant effect on the yield of Inpago 6 and Situ Patenggang, and significant effect on the yield of Situ Bagendit. The average value of clay content in the three soil types was $65 \%$. Clay minerals are very important to soil fraction because they affect water holding capacity and the availability of nutrients in the soil (Rogers et al. 2014). The increase in clay mineral content increases stabilization of organic matter, affects soil acidity, and controls the population and microbial activity in the soil (Kome et al. 2019). Clay texture is suitable for rice growth, consequently low clay content is less suitable for irrigation of rice because of the low nutrient and water holding capacity (Fageria et al. 2011).

The soil water content (SWC) is usually defined as water stored in unsaturated soil layers (He et al. 2012). Our study found that soil moisture content (SMC) had very significant effect in increasing the yield of Ciherang, GM 2, GM 11, GM 28, Inpari 6 Jete, Inpari 33, and IR-64. The average value of SWC in the three soil types was $4.33 \mathrm{~mm}$ $\mathrm{cm}^{-1}$. Water is very important resource for photosynthesis process and plant growth, as such deficit in water supply is one of key environmental stress affecting food crop production (European Union 2014). There is also interaction between soil moisture and nutrients in which soil moisture affects the availability of nutrients in the soil and plant resistance to drought. Rice is more vulnerable to drought compared to other food crops since low water content can reduce microbial biomass $\mathrm{C}$, leaf area, cell size, and volume between cells (Scherer et al. 2017; Xue et al 2017).

Soil organic content (SOC) is a key indicator for assessing soil health and plays a crucial role in increasing crop productivity (Brandão and Canals 2013; Brady et al. 2015). SOC is also an essential element for land sustainability to create safe and healthy products, restore soil fertility, and reduce climate change (Timsina 2018). Positive responses were showed by GM 11, GM 28, Inpago 6 , and Inpari 33 with the increase of soil organic carbon (SOC) in the soil. The average value of SOC in the three soil types was $1.6 \%$. This value can be categorized as very low.

Soil $\mathrm{pH}$ is an essential factor for plant growth. Soil $\mathrm{pH}$ influences nutrient availability and nutrient toxicity, and has a direct effect on the protoplasm of plant root cells (Alam et al. 1999). The average $\mathrm{pH}$ of the three soil types was 7.9, which can be categorized as alkaline. As such, the higher level of soil $\mathrm{pH}$ soil very significantly reduced the yield of Puthu Gunungkidul and Way Apo Buru cultivars, but the higher level of $\mathrm{pH}$ significantly increased the yield of Situ Bagendit. High pH causes the deficiency of iron, manganese, and phosphate while increases boron content, which can cause toxicity to plants (Marschner 2012).

Nitrogen could be a limiting factor for plant growth after fixing carbon (Marschner 2012). The higher level of total nitrogen $(\mathrm{N})$ had a very significant effect on increasing the yield of Ciherang and GM 8. The average value of $\mathrm{N}$ in the three soil types was $0.14 \%$. This value is classified as low. Intensive rice cultivation generally requires a large amount of $\mathrm{N}$ nutrients since $\mathrm{N}$ is the most critical element for increasing the growth, yield, and quality of grain crops (Kichey et al. 2007). Research in Ghana showed that increasing $\mathrm{N}$ content in soils is positively correlated with yield and productivity of rice (Moro et al. 2015). The increase in $\mathrm{N}$ content increased panicle length and weight of 1000 grains by $96 \%$ and $73 \%$, respectively (Fageria et al. 2011).

Magnesium $(\mathrm{Mg})$ is very important for every living organism, including higher plants. $\mathrm{Mg}$ accounts for $0.2 \% \mathrm{~W}$ $\mathrm{w}^{-1}$ (dry weight) and is the most abundant mineral after $\mathrm{N}$, $\mathrm{K}$, and $\mathrm{Ca}$ (Hawkesford et al. 2012). Mg functions in the process of photosynthate distribution, activator of nitrate reductase activity, and RuBP carboxylase (Marschner 2012). A positive response was shown by GM 2 and IR-64 to the increase in Magnesium $(\mathrm{Mg})$ content in the soil. The average value of $\mathrm{Mg}$ in the three soil types was $1.99 \mathrm{cmol}^{(+)}$ $\mathrm{kg}^{-1}$, which is categorized as moderate. $\mathrm{Mg}$ deficiency at moderate levels can reduce the number of spikelets and reduce the weight of grains in rice (Dobermann and Fairhurst 2000). A recent study showed that Mg deficiency caused a decrease in transpiration which occurred before sugar accumulation and chlorosis in rice leaves (Kobayashi et al. 2013).

Iron plays an essential role as a companion nutrient in the formation of enzymes involved in the process of mitochondrial respiration, photosynthesis, synthesis, and repairment of nucleic acids, metal homeostasis, maintaining the structural and functional integrity of protein, and chlorophyll content in rice (Bashir et al. 2017; Li and Tan 2017; Müller et al. 2015; Rout and Saho 2015). An increase in Fe content in the soil had positive impact on the increase of yield of Inpari 6 Jete. The average value of $\mathrm{Fe}$ in the three soil types was $2.30 \mathrm{ppm}$, which can be classified as very low category. In alkaline soils, Fe is oxidized as insoluble iron oxides (Morrissey and Guerinot 2009). This causes the soil at the study site to contain very low Fe. Iron deficiency can cause changes in root morphology (Giehl et al. 2012; Gruber et al. 2013; Morrissey and Guerinot 2009) and chlorosis of young leaves, thereby reducing yield (Kobayashi and Nishizawa 2014).

Soil microorganisms are considered as sensitive indicators of health and soil quality. Soil microorganisms are strongly influenced by crop management (Geisseler et al. 2017). The higher yield of Inpago 4 and Inpago 5 was influenced by the higher amounts of bacteria (Bae) in the soil, while Puthu Gunungkidul and Way Apo Buru showed positive responses with the higher amounts of Fungi $(\mathrm{Fg})$ in the soil. The average value of Bae and Fg in the three soil types were $3.49 \times 10^{6}$ and $2.57 \times 10^{5}$ colony, respectively. These values are considered as low. Soil microorganisms change dynamically with environmental change (Ahn et al. 2012; Zhao et al. 2014). Changes in soil condition by drying the submerged layer will change the microbial activity of the soil where the anaerobic microbes replace the aerobic microbes. The energy for anaerobic material is sourced from the easily reduced oxidized compound, which acts as an electron acceptor like ions $\mathrm{NO}_{3}{ }^{-}, \mathrm{SO}_{4}{ }^{+}, \mathrm{Fe}_{3}{ }^{+}$, and $\mathrm{Mn}_{4}{ }^{+}$(Drury et al. 2003). Microbial content in the soil is also influenced by SOC. In this study, the SOC content was very low so that the amounts of fungi and bacteria were 
also low. The increasing soil microbial activity, namely bacterium, and fungi, significantly increase the content of SOC, total P, and pH (Ahn et al. 2012; Yuan et al. 2013; Dong et al. 2014; Zhao et al. 2014; Zhang et al. 2016; Geisseler et al. 2017). Suryanto et al. (2017a) found that the amounts of soil microorganisms were one determinant of rice yields in $M$. cajuputi agroforestry stands.

Based on the results of this study, we recommend the use of rice cultivars which have high yields in each type of soil at the study site. Rice cultivation recommendations for Lithic Haplusterts, Ustic Epiaquerts, and Vertic Haplustalfs are Situ Patenggang, Situ Patenggang, or GM 28, and GM 28 , respectively. The recommendation of fertilization and soil treatments is based on the limiting factors in each rice cultivars and each soil type. The suggestion for future study is the investigation of the optimum level of such treatments (e.g. fertilizer) to improve soil quality parameters.

\section{ACKNOWLEDGEMENTS}

The research for this article was fully funded by the University of Gadjah Mada, Yogyakarta, Indonesia through the university grant-in-aid scheme under Penelitian Terapan Unggulan Perguruan Tinggi (Contract no. 2885/UN1.DITLIT/DIT-LIT/PT/2020).

\section{REFERENCES}

Ahn JH, Song J. Kim BY, Kim MS, Joa JH, Weon HY. 2012. Characterization of the bacterial and archaeal communities in rice field soils subjected to long-term fertilization practices. J Microbiol 50: 754-765.

Alam SM, Naqvi SSM, Ansari R. 1999. Impact of Soil pH on Nutrient Uptake by Crop Plants. Handbook of Plant and Crop Stress, Madison, USA.

Alam T. 2014. Optimasi Pengelolaan Agroforestri Cengkeh, Kakao dan Kapulaga di Pegunungan Menoreh. [Tesis]. Fakultas Pertanian, Universitas Gadjah Mada, Yogyakarta. [Indonesian]

Alam T, Kurniasih B, Suryanto P, Basunanda P, Supriyanta, Ambarwati E, Widyawan MH, Handayani S, Taryono. 2019. Stability analysis for soybean in agroforestry system with kayu putih. SABRAO J Breed Genet 51(4): 405-418.

Andrews SS, Karlen DL, Mitchell JP. 2002. A comparison of soil quality indexing methods for vegetable production system in Northern California. Agric Ecosys Environ 90: 25-45.

Aubert G, Ollat C, Pinta M. 1954. Analytical methods currently used at IDERT soil laboratories. Inter-African Soils Conference. www.documentation.ird.fr/hor/fdi:11213.

Bashir K, Nozoye T, Nagasaka S, Rasheed S, Miyauchi N, Seki M, Nakanishi H, Nishizawa NK. 2017. Paralogs and mutants show that one DMA synthase functions in iron homeostasis in rice. J Exp Bot 68: 1785-1795.

Bilgili AV, Kucuk C, Van Es HM. 2017. Assessment of the quality of the Harran Plain soils under long-term cultivation. Environ Monit Assess 189: 460.

Black CA. 1965. Methods of Soil Analysis. Part 2. American Society of Agronomy, Madison, Wisconsin, USA.

Blake GR, Hartge KH. 1986. Methods of soil analysis. In: Klute A (eds) Bulk Density. American Society of Agronomy, Madison, Wisconsin, USA.

Boettinger J, Chiaretti J, Ditzler C, Galbraith J, Kerschen K, Loerch C, McDanie P, McVey S, Monger C, Owens P, Ransom M, Scheffe K, Shaw J, Stolt M, Weindorf D. 2015. Illustrated Guide to Soil Taxonomy. Version 2. U.S. Department of Agriculture, Natural Resources Conservation Service, National Soil Survey Center, Lincoln, Nebraska, USA.
Boy R, Indradewa D, Putra ETS, Kurniasih B. 2020. Drought-induced production of reactive oxygen species and antioxidants activity of four local upland rice cultivars in Central Sulawesi, Indonesia. Biodiversitas 21 (6): 2555-2565.

Brady MV, Hedlund K, Cong RG, Hemerik L, Hotes S, Machado S, Mattsson L, Schulz E, Thomsen IK. 2015. Valuing supporting soil ecosystem services in agriculture; a natural capital approach. Agron J 107: 1809.

Brandão M, Canals LMI. 2013. Global characterisation factors to assess land use impacts on biotic production. Intl J Life Cycle Assess 18: 1243-1252.

Cakmak I, Kirkby EA. 2008. Role of magnesium in carbon partitioning and alleviating photooxidative damage. Physiol Plant 133: 692-704.

David AB, Davidson CE. 2014. Estimation method for serial dilution experiments. J Microbiol Methods 107: 214-221.

Dobermann A, Fairhurst T. 2000. Rice; Nutrient Disorders \& Nutrient Management. Handbook series. Potash \& Phosphate Institute, Potash $\&$ Phosphate Institute of Canada, Canada and International Rice Research Institute, Philippines.

Dong WY, Zhang XY, Dai XQ, Fu XL, Yang FT, Liu XY, Sun XM, Wen $\mathrm{XF}$, Schaeffer S. 2014. Changes in soil microbial community composition in response to fertilization of paddy soils in subtropical China. App Soil Ecol 84: 140-147.

Drury CF, Zhang TQ, Kay BD. 2003. The non-limiting and least limiting water ranges for soil nitrogen mineralization. J Soil Sci Soc Am 67: 1388-1404.

European Union. 2012. Sustainable Agriculture for the Future We Want. International Cooperation and Development, European Commission, Brussels, Belgium.

European Union. 2014. Study on Soil and Water in a Changing Environment. European Communities, Luxembourg.

Fageria NK, Carvalho GD, Santos AB, Ferreira EPB, Knupp AM. 2011. Chemistry of lowland rice soils and nutrient availability. Comm Soil Sci Plant Anal 42: 1913-1933.

Fan X, Tang Z, Tan Y, Zhang Y, Luo B, Yang M, Lian X, Shen Q, Miller $\mathrm{AJ}, \mathrm{Xu}$ G. 2016. Overexpression of a $\mathrm{pH}$-sensitive nitrate transporter in rice increases crop yields. Proc Natl Acad Sci 113: 7118-7123.

Feng Y, Balkcom KS. 2017. Nutrient cycling and soil biology in row crop systems under intensive tillage. In: Al-Kaisi MM, Lowery B (eds) Soil Health and Intensification of Agroecosystems. Academic Press, UK.

Geisseler D, Linquist BA, Lazicki PA. 2017. Effect of fertilization on soil microorganisms in paddy rice systems; a meta-analysis. Soil Biol Biochem 115: 452-460.

Giehl RFH, Lima JE, von Wirén N. 2012. Localized iron supply triggers lateral root elongation in Arabidopsis by altering the AUX1-mediated auxin distribution. Plant Cell 24: 33-49.

Giller KE, Tittonell P, Rufino MC, van Wijk MT, Zingore S, Mapfumo P, Adjeinsiah S, Herrero M, Chikowo R, Corbeels M, Rowe EC, Baijukya F, Mwijage A, Smith J, Yeboah E, van der Burg WJ, Sanogo OM, Misiko M, de Ridder N, Karanja S, Kaizzi C, K'ungu J, Mwale M, Nwaga D, Pacini C, Vanlauwe B. 2011. Communicating complexity; integrated assessment of trade-offs concerning soil fertility management within African farming system to support innovation and development. Agric Syst 104 (2): 191-203.

Govaerts B, Sayre KD, Deckers J. 2006. A minimum data set for soil quality assessment of wheat and maize cropping in the highlands of Mexico. Soil Till Res 87: 163-174.

Gruber BD, Giehl RFH, Friedel S, von Wirén N. 2013. Plasticity of the Arabidopsis root system under nutrient deficiencies. Plant Physiol 163: 161-179.

Hajek BF, Adams F, Cope Jr JT. 1972. Rapid determination of exchangeable bases, acidity and base saturation for soil characterization. Soil Sci Soc Am J 36: 436-438.

Haryanto MIT. 2015. Potensi Produksi Daun Kayu Putih pada Berbagai Kelas Diameter di RPH Menggoran, BDH Playen, KPH Yogyakarta. [Skripsi]. Fakultas Kehutanan, Universitas Gadjah Mada, Yogyakarta. [Indonesia]

Hawkesford M, Horst W, Kichey T, Lambers H, Schjoerring J,Skrumsager Møller I, White P. 2012. Functions of macronutrients. In: Marschner H (eds) Mineral Nutrition of Higher Plants. $3^{\text {rd }}$ eds. Academic Press, London.

He ZB, Zhao WZ, Liu H, Chang XX. 2012. The response of soil moisture to rainfall event size in subalpine grassland and meadows in a semiarid mountain range; a case study in northwestern China's Qilian Mountains. J Hydrol 420: 183-190. 
Hinkelman K. Kempthorne O. 2008. Design and Analysis of Experiments. $2^{\text {nd }}$ eds. John Wiley and Sons, USA.

Jaggard KW, Qi A, Ober ES. 2010. Possible changes to arable crop yields by 2050. Philos Trans R Soc Lond B Biol Sci. 365: 2835-2851.

Jamil A, Mejaya MJ, Praptana RH, Subekti NA, Aqil M, Musaddad A, Putri F. 2016. Deskripsi Varietas Unggul Tanaman Pangan 20102016. Badan Penelitian dan Pengembangan Pertanian, Kementerian Pertanian, Jakarta. [Indonesia]

Jones Jr JB. 2001. Laboratory Guide of Exercises in Conducting Soil Test and Plant Analysis. $1^{\text {st }}$ eds. CRC Press, USA.

Kichey T, Hirel B, Heumez E, Dubois F, Le Gouis J. 2007. In winter wheat (Triticum aestivum L.), post-anthesis nitrogen uptake and remobilisation to the grain correlate with agronomic traits and nitrogen physiological markers. Field Crop Res 102: 22-32.

Klee HJ, Tieman DM. 2013. Genetic challenges of flavor improvement in tomato. Trends in Genet 29 (4): 257-267.

Kobayashi NI, Takayuki S, Iwata N, Ohmae Y, Ren I, Keitaro T, Tomoko MN. 2013. Leaf senescence in rice due to magnesium deficiency mediated defect in transpiration rate before sugar accumulation and chlorosis. Physiol Plant 148: 490-501.

Kobayashi T, Nishizawa NK. 2014. Iron sensors and signals in response to iron deficiency. Plant Sci 224: 36-43.

Kome GK, Enang RK, Tabi FO, Yerima BPK. 2019. Influence of clay minerals on some soil fertility attributes; a review. J Soil Sci 9: 155188.

Li W, Lan P. 2017. The understanding of the plant iron deficiency responses in strategy I plants and the role of ethylene in this process by omic approaches. Front Plant Sci 8(40).

Marschner H. 2012. Mineral Nutrition of Higher Plants. $3^{\text {rd }}$ eds. Academic Press, UK.

Moncada MP, Gabriels D, Cornelis WM. 2014. Data-driven analysis of soil quality parameters using limited data. Geoderma 235-236: 271278.

Moro BM, Nuhu IR, Ato E, Nathanial B. 2015. Effect of nitrogen rates on the growth and yield of three rice (Oryza sativa L.) varieties in rainfed lowland in the forest agro-ecological zone of Ghana. Intl J Agric Sci 5 (7): 878-885

Morrissey J, Guerinot ML. 2009. Iron uptake and transport in plants; the good, the bad, and the ionome. Chem Rev 109: 4553-4567.

Müller C, Kuki KN, Pinheiro DT, de Souza LR, Silva AIS, Loureiro ME, Oliva MA, Almeida AM. 2015. Differential physiological responses in rice upon exposure to excess distinct iron forms. Plant Soil 391: 123-138.

Mulyani A, Nursyamsi D, Syakir M. 2017. Strategi pemanfaatan sumberdaya lahan untuk pencapaian swasembada beras berkelanjutan Jurnal Sumberdaya Lahan 11(1): 11-22. [Indonesian]

Olsen SR, Cole CV, Watanabe FS, Dean LA. 1954. Estimation of Available Phosphorus in Soils by Extraction with Sodium Bicarbonate. United States Department of Agriculture, Washington, USA.

Piepho HP, Nazir MF, Qamar M, Rattu AUR, Din RU, Hussain M, Ahmad G, Subhan FE, Ahmad J, Abdullah, Laghari KB, Vistro IA, Kakar MS, Sial MA, Imtiaz M. 2016. Stability analysis for a countrywide series of wheat trials in Pakistan. Crop Sci 56: 2465 2475.

Richards LA. 1954. Diagnosis and improvement of saline and alkali soils. Department of Agriculture, Washington, USA.

Rogers DH, Aguilar J, Kisekka I, Barnes PL, Lamm FR. 2014. Soil, Water, and Plant Relationships. Kansas State University Research and Extension, USA.

Rousseau GX, Deheuvels O, Arias IR, Somarriba E. 2012. Indicating soil quality in cacao-based agroforestry system and old-growth forests; the potential of soil macrofauna assemblages. Ecol Ind 23: 535-543.

Rout GR, Sahoo S. 2015. Role of iron in plant growth and metabolism. Rev Agric Sci 3: 1-24.

SAS Institute. 2013. SAS System for Windows 9.4. SAS Institute, Inc., North Carolina, USA.

Scherer TF, Franzen D, Cihacek L. 2017. Soil, Water, and Plant Characteristics Important to Irrigation. NDSU Extension Service, North Dakota State University, USA.
Statistics Indonesia. 2020. The harvested area and rice production in Indonesia 2019. Statistics Indonesia, Jakarta, Indonesia. www.bps.go.id/pressrelease/2020/02/04/1752/luas-panen-danproduksi-padi-pada-tahun-2019-mengalami-penurunan-dibandingkantahun-2018-masing-masing-sebesar-6-15-dan-7-76-persen.html.

Stenholm A, Holmstrom S, Ragnarsson A. 2009. Total nitrogen in wastewater analysis; comparison of devarda's alloy method and hightemperature oxidation followed by chemiluminescence detection. J Anal Chem 64: 1047-1053.

Suryanto P, Faridah E, Nurjanto HH, Supriyanta, Kastono D, Putra ETS, Handayani S, Dewi AK, Alam T. 2020a. Influence of siam weed compost on soybean varieties in an agroforestry system with kayu putih (Melaleuca cajuputi). Biodiversitas 21 (77): 062-3069

Suryanto P, Faridah E, Triyogo A, Kastono D, Suwignyo B, Nurmalasari AI, Alam T. 2020. Designing of soil quality and climate assessment tool for sustainable production of signal grass (Brachiaria brizantha) silvopasture system in mountain ecosystems. Aust J Crop Sci 14 (4): 614-621.

Suryanto P, Kurniasih B, Faridah E, Nurjanto HH, Rogomulyo R, Handayani S, Kastono D, Muttaqien AS, Alam T. 2020. Influence of furrow with organic material and Chromolaena odorata compost on upland rice productivity in an agroforestry system with Melaleuca cajuputi. Biodiversitas 21: 780-791.

Suryanto P, Tohari, Putra ETS, Alam T. 2017. Minimum soil quality determinant for rice and 'kayu putih' yield under hilly areas. J Agron 16: $115-123$.

Suryanto P, Tohari, Putra ETS, Alam T. 2017. Soil quality assessment for yield improvement of clove, cacao and cardamom agroforestry system in Menoreh mountains area, Indonesia. J Agron 16: 160167.

Suryanto P, Tohari, Sulistyaningsih E, Putra ETS, Kastono D, Alam T. 2017. Estimation of critical period for weed control in soybean on agroforestry system with kayu putih. Asian J Crop Sci 9 (3): 82-91.

Timsina J. 2018. Can organic sources of nutrients increase crop yields to meet global food demand?. Agron 8 (214): 1-20.

Van Reeuwijk LP. 1993. Procedures for soil analysis. International Soil Reference and Information Centre, Wageningen University, Nederland.

Wahab MI, Satoto, Rachmat R, Guswara A, Suharna. 2017. Deskripsi Varietas Unggul Baru Padi. Badan Penelitian dan Pengembangan Pertanian, Kementerian Pertanian, Jakarta. [Indonesia]

Wahyunto, Hikmatullah, Suryani E, Tafakresnanto C, Ritung S, Mulyani A, Sukarman, Nugroho K, Sulaeman Y, Apriana Y, Suciantini, Pramudia A, Suparto, Subandiono RE, Sutriadi T, Nuryamsi D. 2016. Pedoman Penilaian Kesesuaian Lahan untuk Komoditas Pertanian Strategis Tingkat Semi Detail Skala 1:50.000. Balai Besar Litbang Sumberdaya Lahan Pertanian, Badan Penelitian dan Pengembangan Pertanian, Bogor. [Indonesia].

Xue R, Shen Y, Marschner, P. 2017. Soil water content during and after plant growth influence nutrient availability and microbial biomass. J Soil Sci Plant Nutr 17 (3): 702-715.

Yao R, Yang J, Gao P, Zhang J, Jin W. 2013. Determining minimum data set for soil quality assessment of typical salt-affected farmland in the coastal reclamation area. Soil Till Res 128: 137-148.

Yuan H, Ge T, Zhou P, Liu S, Roberts P, Zhu H, Zou Z, Tong C, Wu J. 2013. Soil microbial biomass and bacterial and fungal community structures responses to long-term fertilization in paddy soils. J Soils Sediments 13: 877-886.

Zaini Z, Abdurrahman S, Widiarta N, Wardana P, Setyorini D, Kartaatmadja S, Yamin M. 2016. Pedoman umum ptt padi sawah. Badan Penelitian dan Pengembangan Pertanian, Kementerian Pertanian, Jakarta.

Zhang Q, Liang G, Zhou W, Sun J, Wang X, He P. 2016. Fatty-acid profiles and enzyme activities in soil particle-size fractions under long-term fertilization. Soil Sci Soc Am J 80: 97-111.

Zhao J, Ni T, Li Y, Xiong W, Ran W, Shen B, Shen Q, Zhang R. 2014. Responses of bacterial communities in arable soils in a rice-wheat cropping system to different fertilizer regimes and sampling times. PLoS ONE 9 (1): e85301. DOI: 10.1371/journal.pone.0085301 